\section{Oleksandr Bezruchko}

Doctor in Art Studies, Professor of the Department of Cinema and Television Art of the Kyiv National

University of Culture and Arts

\section{Олександр Безручко}

Аоктор мистецтвознавства, професор кафеАри кіно

і телемистецтва Київського національного універси-

тету культури і мистецтв

тем. / tel: +380673163826 e-mail: oleksandr_bezruchko@ukr.net orcid.org/0000-0001-8360-9388

\title{
Specifics of the First Lecture of O. Dovzhenko in Kyiv State Institute of Cinematography
}

\author{
Специфіка першої мекції О. П. Аовженка \\ у Київському державному інституті кінематографіі
}

\begin{abstract}
Specifics of the first lecture of the brilliant Ukrainian film director O. Dovzhenko, held in Kyiv State Institute of Cinematography, is researched and analized. The pedagogical activity of the Ukrainian director was investigated; the fact of inviting the artist to teach a group of students of the film institute was established; his first lecture at the Kyiv State Institute of Cinematography was reconstructed, based on the author's findings: transcripts of the first lecture of O. Dovzhenko in the Kyiv State Institute of Cinematography in the main Ukrainian and Russian archives.

Keywords: film director, Oleksandr Dovzhenko's films, history of cinema, Kyiv State Institute of Cinematography, students, first lecture.
\end{abstract}

Problem statement. The urgency of this research is caused with the lack of special studies of the pedagogical activity of O. Dovzhenko in Ukraine, therefore it is nessesary to create a complete and objective biography of the artist and outline his influence on the formation and development of Ukrainian cinema education in the 1930s and 1940s, to shed light on the obscure moments of of Dovzhenko's biography, to discover and publish an unknown layer of sources from previously classified state and personal archives, special storages, and libraries.

Analysis of recent research and publications. In the studies of M. Shudra $[17 ; 18 ; 19]$, L. Cherevatenko [16], V. Marochko [9], V. Mislavskyi [10] and others, O. Dovzhenko's life and work have been studied thorouhghly and comprehensively, still, his cinema-pedagogical activitity is mentioned very briefly $[1 ; 2]$.

Objectives of this research are to study and analyze the specifics of the first lecture of Ukrainian feature films director O. Dovzhenko at the Kyiv State Institute of Cinematography; to reveal the fact of inviting the artist to teach a group of students of the film institute; to reconstruct his first lecture at the Kyiv State Institute of Cinematography; to consider the possibility of finding the transcripts of the first lecture made by O. Dovzhenko at the Kyiv State Institute of Cinematography in the main Ukrainian and Russian archives.

Presentation of the main research material. The first meeting of the Kyiv State Institute of Cinematography students with O. Dovzhenko took place in the 1930, a very difficult year for Dovzhenko's film Earth. The first-year students of the Kyiv State Institute of Cinematography decided to approach Dovzhenko in his hotel room, where the artist lived at the time. "We wanted," recalled the former student of this educational institution T. Levchuk, "to invite him to read the cycle of lectures for our course on the problems of filmmaking at the time, convenient for him. The management of the institute believed that this kind of student action would substantially reinforce the official offer" [7, p. 53].

In total, according to the memoirs of another former student of this institute G. Grigoriev [4, p. 223], there were ten persons: T. Levchuk, G. Grigoriev, V. Nechaev, M. Yakubov, the names of other students niether Levchuk, nor Grigoriev did not remember.

Dovzhenko considered it expedient to share with the students his own thoughts about the true and fake art, about the director and craftsman, about the creation of the image, standard thinking and the danger of cliches. The whole improvised lecture of a recognized master for the young film directors was built on a detailed analysis of his film Earth. One of the students, G. Grigoriev, took notes of this conversation. Oleksandr Dovzhenko asked his young colleague if he remembered and understood everything, or just thoughtlessly stenographed it, "It happens that a student makes good notes, but does not think about the content" [4, p. 229].

T. Levchuk also recalled this meeting with the master very briefly. However, after analyzing the memoirs and comparing them with Dovzhenko's printed statements, we can reconstruct this conversation-lecture with a certain degree 
of probability, given that Dovzhenko "did not follow any system in his conversations" [3, p. 186], and therefore never repeated anything in detail, always lecturing in a new way.

So, first of all, the young film directors were interested in everything that was related to the Earth, Dovzhenko's last film, which caused significant, sometimes extreme, controversy. It was a painful topic for Dovzhenko as a film director at that time, still, Dovzhenko-teacher could not reject the students, "To tell the truth, I was sick of talking about it ... But for you, my young friends, it is worth talking" [4, p. 224].

In any work, Oleksandr Dovzhenko tried to find a non-standard move that would transfer a film from a craft product into a work of art. Prior to this he taught his students, "Beware of plague, one dangerous thing-standard thinking" [4, p. 226].

The master had no secrets from the young film directors about his own creativity and artistic preference, but on the contrary (which was one of the characteristic features of his cinema-pedagogical method), in detail analyzed his own work in his lecture-conversations and generously shared his secrets with his students. For instance, the Earth was built on a paradox, "An optimistic film that has to provoke optimism in the masses is based on two deaths: the film begins with the death of an old peasant who has already reached old age and who does not hesitate to die; and the second death $\langle\ldots\rangle$ a victim for the sake of a new life $<\ldots>$ The moment of the murder therefore becomes a completely different character" [16, p. 5].

When one of the students doubted the expediency of showing the "whimsical old pope", which did not resemble much the image of the enemy, cultivated in those days, Dovzhenko warned the young artists against the development of the pattern thinking, "Yakubov's question reminded me of some of our posters, where the rich peasant (then called 'kulak' in Russian, 'kurkul' in Ukranian) is always thick, with a predatory look, the pop is similarly ugly, scary" [4, p. 226].

The first conversation with the Kyiv State Institute of Cinematography students was very long, and only in the end youngsters dared to ask O. Dovzhenko to teach them, "As for your request and suggestions, I will tell you sincerely-I am terribly tired $\langle\ldots\rangle$ But on the benevolent thing, which your request is, I will respond with a kind word" [7, p. 54].

According to G. Grigoriev, "there were several students in our group, however few, who were indifferent to everything in the world. They attended, as if doing some great service. So some of them said, 'If he comes, we will listen, but we could live without it as well” [4, p. 223]; besides, in the first few months attendance of students was a serious problem, especially among high school students [11, p. 35]. Nevertheless, during the first Dovzhenko's lecture in the Kyiv State Institute of Cinematography the room was full.

The students memorized the introductory lecture by O. Dovzhenko for good, as is became a life plan for some, "Oleksandr Petrovych impressed us with the passion of his language; the same passion and enthusiasm permeated all his work, making his films look like inspirational songs" [6, p. 5]. A characteristic feature of Dovzhenko's pedagogical talent was a strong charisma, multiplied by the almost hypnotic ability to engage the audience, "He spoke with the gradually rising animation and persuasiveness, like a beautiful artist, the only difference is that Dovzhenko produced his monologue impromptu, without preliminarily memorizing the text. The words went on and on, I wanted to listen to them forever" [4, p. 226-227].

Unfortunately, the transcripts of this lecture have not been preserved ("the years of war have dispelled all student notes and almost verbatim records of the first introductory lecture of a good and clever master, director, artist and without an exaggeration-the great teacherDovzhenko" [8, p. 69]). Still, based on the lectures and reflections of Oleksandr Dovzhenko in the articles, we can with a certain degree of probability reconstruct the main ideas that he wanted to convey to young artists.

The first thing that O. Dovzhenko started his lecture with was his vision of the film director's profession (in fact, that instantly captured attention of the directing faculty students), "I sincerely congratulate you all on the victory in the great competition-stepping to the thorny path of serving people in the field of art, I would like to share with you my personal reflections on the role and place of the artist, and hence the director, in the overall cultural process of his nation. Since I chose the director's career for myself, I will address mainly the future filmmakers" [8, p. 69].

The teacher tried to engage his students with:

1. Personalities at the forefront of serving the ideals of the people: "Dovzhenko then talked about the beauty and power of the cinema, about the difficulties that will be on our way and which we should not be afraid of, of the high calling of the artist who linked his fate with cinema, about his service to his people" $[6$, p. 5$]$.

2. Professionals who should not forget that "we are not only citizens, but also artists, directors" [4, p. 226].

Students liked that Dovzhenko did not refere to his authority during the lecture, "Recalling the fiery words of O. Dovzhenko, I note, first of all, his passion and the feeling of deep conviction in the presentation of only his own thoughts and only his own beliefs... Everything went from his own personality, from a big and kind heart" [8, p. 69].

The artist declared the rejection of the concept, when "the student plots a large number of very clear and perfect formulations that are planted in his mind as exact truths, but they end up with nothing, if they are not the result of some great creative installation $<\ldots$ > If you will produce at least a couple of your own conclusions, then I consider it my little merit" [15, p. 21].

Can anyone teach a creative profession, for example, a filmmaking? This question arose in connection with the tasks of the Five-Year Plan, which envisaged an "increase in the proletarian core" within the artistic environment; a rather large percent of students enrolled into the Kyiv State Institute of Cinematography not because of creative selection, but due to directives of numerous institutions, organizations and labor collectives [12, p. 24]. 
Such a situation could not but disturb the leading teachers and specialists in the field of cinema. At the First All-Ukrainian Congress of the Friendship Society of Soviet Photography and Cinematography, O. Dovzhenko urged "to solve the problem of personnel not only in the quantitative sense, that is, to recruit children of industrial and collective farm workers" $[14$, p. 5], because "the film director cannot become the person who, as people say, is 'as bold as brass"” $[7$, p. 55].

Dovzhenko's friend, O. Gavronsky, a brilliant teacher of film-making in the Kyiv State Institute of Cinematography, openly expressed his belief in the dominance of talent over social origin. Gavronsky would soon be expelled from the institute and arrested, his name for many decades would be cited only along with the terms "Trotskyism" and "a group society".

For Dovzhenko, the main thing in the students was the presence of talent (the set for the Film Directors' Laboratory at the Kyiv Film Factory will be a vivid confirmation of this) and not the social origin, so the artist could not omit this topic in his first lecture, although in a slightly veiled form, "As for the film director profession, I have to immediately warn my young colleagues, who would be perhaps disappointed: I am convinced that nobody is able to learn film directing in four years" $[7, \mathrm{p} .55]$.

Dovzhenko mastered all the subtleties of cinematic art independently, "on the go", in the rather harsh conditions of real film production. Nevertheless, perhaps taking into account his first profession of a teacher and his own openness, he constantly shared the secrets of directing with young artists, willingly analyzed his own films, miscalculations and achievements, and therefore declared his own, so-called "synthetic creative method", "Of the vast amount of material, it would be enough to create five, six films. I created a single film, which is extremely powerful. This is a condensation of the material into a single whole" [16, p. 4].

The second important component of the film director's method, which the artist could not tell the students of Kyiv State Institute of Cinematography of, was the so-called typing method of the Soviet cinema, used at that time by Dovzhenko in his own work, "I choose the characters of the film so that they have the features, characteristic not only of the film heroes, but of the whole social group" [16, p. 4].

O. Dovzhenko, especially after Zvenigora, have been thrown back by the fact that his films are incomprehensible to the working people, therefore the artist was forced to explain his own position to the students, "To create such a movie, which the viewer would attend several times $\langle\ldots\rangle$ In the history of art, there were cases, when the work of art was at the level of understanding of the multimillion mass. Cinematography only needs to realize this" [16, p. 5].

In his 1932 lecture, Dovzhenko confessed to the students with a pity, "This is my mistake as well. Since I am the author of my scripts, I make them myself and live with the ideas that I put into my stuff for years, so I often forget about the viewer. I forget that the viewer should be a thou- sand times wiser than me to swallow during hour and a half all that I've been investing in the picture for years. And this never happens" [15, p. 3-4].

To improve this situation, Oleksandr Dovzhenko believed it was necessary to create favorable conditions for the viewer to have a chance to review films, which claim to be the works of art, for several times, "We can repeatedly contemplate the paintings of Raphael and Rembrandt, read Byron and Goethe, listen to Beethoven, to look at the Shakespeare theater, why could not it be pensive to watch the art film more than just once?" $[16$, p. 5].

This was a rather interesting attempt to justify the "arthouse", which was realized in Moscow in the mid-thirties with the opening of the House of Cinema and amid vain attempts to establish a similar space in the late 1930s in Kyiv. Dovzhenko denied the fatal condemnation of any cinematography for "aging". Perhaps the viewer is only interested in the new films, regardless of their quality. He puts films in line with masterpieces of traditional arts. Nowadays, modern technical possibilities allow the film to be perceived by certain fragments, revisit them again, stop and reflect, as it happenes with a book or a painting in a museum.

So, O. Dovzhenko set at least three main tasks to the young cinematographers:

1. To treat cinema as a serious kind of art, and not as an entertainment, so-called "cinema", "We cannot approach the film as a passion for art, because its aim is very important" [16, p. 5].

2. In the future creative life there should not be artisans, but only artists. "Free the film from its current mercenary status and create a film that is an equal son of art" [16, p. 5].

3. To make only high-quality feature films that could be considered true works of art.

Dovzhenko thoroughly analyzed the Earth, in which he "shifted the center of gravity to a man" [5, p. 187], and therefore urged students to carefully study "their psychology, hopes, struggles, dreams - what constitutes the core of their existence. Otherwise, in our films there will be no real life, but only fictitious one, false, boring and needed by noone" [4, p. 227].

O. Dovzhenko, as a master of improvisation, was not disposed to writing his own lectures down and wished that the students perceived his lecture not verbally but with their hearts; not through words, but through emotions that united the teacher and his disciples, making them like-minded people, soulmates. This is especially emphasized in the memories of Kyiv and Moscow students.

Unfortunately, Grigoriev's arrest in 1937 led to the fact that the abstracts of this and subsequent lectures were not preserved. Having become acquainted with the case of Grigory Grigoriev, now rehabilitated (his real name was Prokoppshin) $[13$, p. 8$]$, researchers stated that there were no notes in the case materials (comparing, for example, with the student scenarios of the repressed director, preserved by his laboratory assistant Teodoziy Ferentz). Most likely, the abstracts of the lectures by Dovzhenko did not benefit for this investigative case and were destroyed. 
Conclusions. We set ourselves the goal to investigate and analyze the first lecture of O. Dovzhenko, the Ukrainian feature films director, at the Kyiv State Institute of Cinematography. The goal was achieved.

Summerizing the abovementioned, it can be noted that the scientific tasks have been fulfilled: the pedagogical activity of the Ukrainian director was investigated; the fact of inviting the artist to teach a group of students of the film institute was established; his first lecture at the Kyiv State Institute of Cinematography was reconstructed. We considered the possibility of finding the first transcripts of the first lecture of O. Dovzhenko in the Kyiv State Institute of Cinematography and in the main Ukrainian and Russian archives.

Prospects for the further research. Despite the thorough scientific research of the first lecture at the Kyiv State Institute of Cinematography, we believe that the perspectives for scientific research remain significant, since the transcript of this lecture has not yet been found.

\section{References}

1. Bezruchko O.V. PedagogIchniy metod O.P. Dovzhenka: navchalniy posibnik; Kyiv. mizhnar. un-t. Kyiv: KiMU, 2012. T. 1. $266 \mathrm{s.}$

2. Bezruchko O.V. Pedagogichniy metod O.P. Dovzhenka: navchalniy posibnik; Kyiv. mizhnar. un-t. Kyiv: KiMU, 2012. T. 2. 238 s.

3. Halytskyi V. Vernuvshys v proshloe // Uroky Aleksandra Dovzhenko. Kyiv: Mystetstvo, 1982. S. 183-192.

4. Hryhoriev H. Shcho bulo, te bachyv. Kyiv: Radianskyi pysmennyk, 1966. $231 \mathrm{~s}$.

5. Dovzhenko O.P. Tvory: u 5 t. / uporiad. Yu. I. Solntsevoi, T. P. Derevianko. Kyiv: Dnipro, 1984. T. 4: Statti, vystupy, lektsii. 352 s. 6. Levchuk T.V. S lyubovyu k zritelyu / lit. zapis I.Rachuka, V. Chernogo. Moskva: SK SSSR, Byuro propagandyi Sov. kinoiskusstva, 1974. $64 \mathrm{~s}$.

7. Levchuk T.V. Tomu shcho liubliu: spohady kinorezhysera. Kyiv: Mystetstvo, 1987.200 s.

8. Levchuk T. Pershe storichchia yoho bezsmertia // Muzei Natsionalnoi kinostudii khudozhnikh filmiv im. Oleksandra Dovzhenka. F. Levchuk Tymofii Vasylovych.

9. Marochko V. Zacharovaniy Desnoyu: Ist. portret O. Dovzhenka. Kyiv: Vidavn. dim «Kievo-Mogil. akad.», 2006. 285 s.

10. Oleksandr Dovzhenko: malovidomi storinki / peredm., uporyad. V.N. Mislavskiy. Harkiv: Dim reklami, 2015. 280 s.

11. Tsentralnyi derzhavnyi arkhiv vyshchykh orhaniv vlady ta upravlinnia Ukrainy (TsDAVO Ukrainy). F. 1238. Op. 1. Spr. 193.

12. TsDAVO Ukrainy. F. 1238. Op. 1. Spr. 196.

13. Tsentralnyi derzhavnyi arkhiv hromadskykh obiednan Ukrainy (TsDAHO Ukrainy). F. 263. Op. 1. Spr. 46283.

14. Tsentralnyi derzhavnyi arkhiv-muzei literatury i mystetstva Ukrainy (TsDAMLM Ukrainy). F. 690. Op. 4. Spr. 74.

15. Tsentralnyi derzhavnyi arkhiv-muzei literatury i mystetstva Ukrainy (TsDAMLM Ukrainy). F. 690. Op. 4. Spr. 101.

16. Cherevatenko L. Prazka storinka O.P. Dovzhenka // Noviny kinoekrana. 1985. \# 9. S. 4-5.

17. Shudria M. Henii naishchyrishoi proby. Narysy. Rozvidky. Retsenzii. Interviu. Publikatsii. Kyiv: Yunivers, 2005. 382 s.

18. Shudria M. Sviashchenni myti osiaiannia // Dnipro. 2004. \# 9/10. S. 72-79.

19. Shudrya N. Yulka i ee Zaporozhets // Aspektyi. 2004. 1-7 okt. S. 7.

\section{Мітература}

1. Безручко О.В. ПеАагогічний метод О.П. Аовженка: навч. посіб. Київ. міжнар. ун-т. Київ: КиМУ, 2012. Т. 1.266 с.

2. Безручко О.В. ПеАагогічний метоА О.П. Аовженка: навчальний посібник; Київ. міжнар. ун-т. Київ: КиМУ, 2012. Т. 2. 238 с.

3. Галиикий В. Вернувшись в прошлое // Уроки Александра Аовженко. Київ: Мистецтво, 1982. С. 183-192.

4. Григор'єє Г. Що було, те бачив. Київ: РаАянський письменник, 1966. $231 \mathrm{c}$.

5. Аовженко О.П. Твори: У 5 т. / Упоряд. Ю.І. Солнцевої, Т.П. Аерев’янко. Київ: Аніпро, 1984. Т. 4: Статті, виступи, мекції. $352 \mathrm{c}$.

6. Аевчук Т.В. С мюбовью к зрителю / мит. запись И.Рачука, В. Черного. Москва: СК СССР, Бюро пропаганды сов. киноискусства, 1974. 64 с.

7. Аевчук Т.В. Тому що мюблю: спогади кінорежисера. Київ: Мистецтво, 1987.200 с.

8. Аевиук Т.Першесторіччя його безсмертя / / Музей Національної кіностудії художніх фільмів ім. Олександра Аовженка. Ф.: Аевчук Тимофій Васильович.

9. Марочко В. Зачарований Аесною: іст. портрет О.Аовженка. Київ: Видавн. Аім «Києво-Могил. акаА.», 2006. 285 с.

10. Олександр Аовженко: маловідомі сторінки / передм., упоряд.

В.Н. Миславський. Харків: Аім реклами, 2015. 280 с.

11. Центральний Аержавний архів вищих органів вмади та управління України (ЦААВО України). Ф. 1238. Оп. 1. Спр. 193.

12. ЦААВО України. Ф. 1238. Оп. 1. Спр. 196.

13. Центральний Аержавний архів громадських об’єАнань України (ЦААГО України). Ф. 263. Оп. 1. Спр. 46283.

14. Центральний Аержавний архів-музей мітератури і мистецтва України (ЦААМАМ України). Ф. 690. Оп. 4. Спр. 74.

15. Центральний державний архів-музей мітератури і мистецтва України (ЦААМАМ України). Ф. 690. Оп. 4. Спр. 101.

16. Череватенко $\Lambda$. Празька сторінка О.П. Аовженка // Новини кіноекрана. 1985. № 9. С. 4-5.

17. Шудря М. Геній найщирішої проби. Нариси. РозвіАки. Рецензії. Інтерв’ю. Публікації. Київ: Юніверс, 2005. 382 с.

18. Шудря М. Священні миті осяяння // Аніпро. 2004. №9/10. C. $72-79$.

19. Шудря Н. Юлька и ее Запорожец // Аспекты. 2004. 1-7 окт. C. 7. 


\section{Безручко О.В.}

\section{Специфіка першої мекції О.П. Аовженка у Київському державному інституті кінематографії}

Анотація. У статті проаналізовано специфіку першої кекції геніального українського кінорежисера О. П. Аовженка у Київському Аержавному інституті кінематографії: досліАжено педагогічну діяльність українського режисера; встановлений факт запрошення митця до викладання групою студентів кіноінституту; реконструйовано його першу мекцію у Київському Аержавному інституті кінематографії; з'ясовано можливість знаходження в основних українських і російських архівах стенограм першої мекції О.П. Аовженка у Київському державному інституті кінематографії.

К^ючові слова: кінорежисер, творчість О.П. Аовженка, історія кіно, Київський державний інститут кінематографії, студенти, перша мекція.

\section{Безручко А. B.}

\section{Специфика первой мекции А.П. Аовженко в Киевском госуАарственном институте кинематографии}

Аннотация. В статье проанализирована специфика первой кекции гениального украинского кинорежиссера А. П. Аовженко в Киевском государственном институте кинематографии: исследована педагогическая деятельность украинского режиссера; был установлен факт приглашения артиста учить группу студентов киноинститута; реконструирована его первая мекция в Киевском государственном институте кинематографии; выяснена возможность нахожАения в основных украинских и российских архивах стенограммы первой мекции А. Аовженко в Киевском государственном институте кинематографии.

Ключевые слова: кинорежиссер, творчество А. П. Аовженко, история кино, Киевский госуАарственный институт кинематографии, студенты, первая мекция. 